Al-Manhaj: Jurnal Hukum dan Pranata Sosial Islam

Vol. : : 1 (2), 2019, 124-154

P-ISSN : 2686-1607

E-ISSN : 2686-4819

\title{
CORRUPTION IN THE TEXT AND CONTEXT OF THE QUR'AN: Maudhu'i's Interpretation Approach
}

\author{
Suad Fikriawan, Abdul Kholiq, Kaukabilla Alya Parangu \\ Institut Agama Islam Sunan Giri Ponorogo, Institut Agama Islam Negeri \\ Ponorogo, Institut Agama Islam Negeri Ponorogo \\ email: suadfikriawan@gmail.com, abdulkholiq1622@gmail.com, \\ kaukabilla@gmail.com
}

Abstract: This article aims to define the meaning of corruption through the text of the Qur'an and contextualize it in the example of the practice of violations committed by several groups of state and regional organizations. The author tries to use the maudhu'i interpretation approach because there are not many studies using this approach and specifically about corruption. Likewise in the Islamic perspective, the text of the Qur'an mentions several terms of corruption such as al-dalw (AlBaqarah: 188), ghulul (Ali Imran: 161), saraqah (Al-Maidah: 38), and al suht (Al-Maidah: 42), which in its context experienced an expansion of meaning along with the development of corruption cases that occurred in Indonesia. For example the word al-dalw (Al-Baqarah: 188) implies enriching oneself or others, abuse of authority, and bribery. Ghulul (Ali Imran: 161) implies enriching oneself or others, harming state finances, abuse of authority, embezzlement, gratuity. Then Saraqah (Al-Maidah: 38) implies enriching oneself or another person, harming state finances, abuse of authority, embezzlement. And lastly al-suht (Al-Maidah: 42) implies enriching oneself or others, abuse of authority, bribery

Keywords: Corruption, Maudhu'i Approach, Qur'an

Abstrak: Artikel ini bertujuan untuk mendefinisikan arti korupsi melalui teks al-Qur'an dan mengontekstualisasikannya dalam contoh praktik pelanggaran yang dilakukan oleh beberapa kelompok organisasi negara dan regional. Penulis mencoba menggunakan pendekatan interpretasi 
maudhu'i karena tidak banyak penelitian yang menggunakan pendekatan ini dan khususnya tentang korupsi. Demikian juga dalam perspektif Islam, teks al-Qur'an menyebutkan beberapa istilah korupsi seperti al-dalw (AlBaqarah: 188), ghulul (Ali Imran: 161), saraqah (Al-Maidah: 38), dan al suht (Al-Maidah: 42), yang dalam konteksnya mengalami perluasan makna seiring dengan perkembangan kasus korupsi yang terjadi di Indonesia. Misalnya kata al-dalw (Al-Baqarah: 188) menyiratkan memperkaya diri sendiri atau orang lain, penyalahgunaan wewenang, dan penyuapan. Ghulul (Ali Imran: 161) menyiratkan memperkaya diri sendiri atau orang lain, merusak keuangan negara, penyalahgunaan wewenang, penggelapan, gratifikasi. Kemudian Saraqah (Al-Maidah: 38) menyiratkan memperkaya diri sendiri atau orang lain, merugikan keuangan negara, penyalahgunaan wewenang, penggelapan. Dan terakhir al-suht (AlMaidah: 42) menyiratkan memperkaya diri sendiri atau orang lain, penyalahgunaan wewenang, penyuapan.

Kata Kunci: Korupsi, Pendekatan Maudhu, al-Qur'an

\section{INTRODUCTION}

Corruption is a human crime that has almost been committed by many countries in the world, both in industrial countries and developing countries. In Indonesia, corruption has become an acute disease, pervading the joints of social life and government, and has deeply rooted in the culture of life, behavior, and way of thinking of most people. The network of corruption seems to have really been woven in all sectors of life, from the palace to the village level. Corruption has plagued the bureaucracy from the top to the bottom, people's representative institutions, military institutions, the business world, banks, social organizations, education, religious institutions, and even institutions tasked with eradicating corruption, such as the police, justice and prosecutors. Meanwhile, the Indonesian government's political will is still struggling due to conflicting interests of various parties. This fact really reduces hopes to eradicate corruption in this Muslim-majority country. Ironically, in many verses of the Qur'an and the hadith of the Prophet, various terms mentioned have hinted at the crime of corruption 
but the appreciation and understanding of the Indonesian Muslim community in practice is still far from the ideals of the Qur'an. ${ }^{1}$

The most substantive loss from acts of corruption is to seize the rights of others, in fact, widely the whole people feel the adverse effects of corruption and the economic system becomes very disturbed. While in the teachings of Islam, corruption is an act that is contrary to the principles of justice, accountability, and responsibility. Corruption with all its negative effects that cause various distortions and damage to the life of the state and society, can be categorized as an acts of dhalim and hated by God, moreover it is able to damage the world order. Meanwhile, according to Transparency International Indonesia (TII) in 2010 it was stated that Indonesia, which is predominantly Muslim, ranked 110th out of 178 in the number of countries surveyed by the CPI (Corruption Perception Index) 2.8. In Southeast Asia, Indonesia ranks fourth out of 10 countries surveyed based on the corruption perception index. This means that corrupt behavior carried out in various fields is not accompanied by a good understanding by the community related to the magnitude of the risk resulting from corruption crime, so that the culture of corruption is difficult to be eliminated. ${ }^{2}$

Another thing that makes it complicated to deal with corruption is a statement put forward by some people that corruption is only a small sin and is considered as normal, or even considered to be very reasonable if carried out by officials or former officials. Even more naive, this kind of opinion is supported by religious circles by proposing the concept of kafarah al-Dhunub, penance. As a result, after some of the corruptors were legally processed, they felt safe and calm after "paying"

1 Nurul Irfan, "Azyumardi Azra" Korupsi dalam Hukum Pidana Islam, (Jakarta: Amzah, 2012), xi

2 Irfan, xi. 
it with much worships, such as umrah or financing others for umrah, helping the poor, the needy, orphans, building mosques and give alms. Of course, this way of thinking and understanding religion is very wrong. Assuming corruption is easily redeemed by just virtuous deeds, prayer, umrah, which cannot be justified. It must be stressed that corruption is not a small sin, but a big sin because clearly the negative impact is huge on all people, nation and state. There have been many theoretical and practical steps launched by the government in the effort to eradicate corruption in this country. For example, in the era of Susilo Bambang Yudhoyono's administration (SBY), eradicating corruption was still a priority and the main agenda, the Corruption Eradication Commission (KPK) in recent years has increasingly been fond of monitoring and arresting officials who commit acts of corruption, the results showed quite significant because it has been proven that many state officials had been sentenced to prison. ${ }^{3}$

In line with this issue, studies and research on corrupt behavior through various perspectives such as the perspective of sociology, psychology, politics, economics, and law may have been done a lot. However, serious studies of corruption in the perspective of the Qur'an is scarce. In fact, such an approach is very interesting and useful in an effort to make a scientific contribution as well as enrich the treasures of Islamic thought in the field of interpretation of the Qur'an. The study is focused on discussing the text and context of the corruption verses and their contextualization in cases occured in Indonesia.

\section{CORRUPTION IN THE HISTORICAL STAGE}

Initially, the term corruption can be found in Latin, which is corruption or corruptus which in English becomes corruption or corrupt. Etymologically corruption means decay, depravity, dishonesty, bribery, 
immorality, deviation from holiness, insulting words or slandering. Robert Klitgaard defines the word corruption in terminology, that is "corruption is the abuse of public power for private benefits". Andi Hamzah, in his legal dictionary defines corruption as an act of bad, rotten, depraved, like being bribed, acts that insult or slander, deviate from holiness and immorality. Meanwhile, according to J.C.T Simorangkir in his legal dictionary gives the understanding that corrupt means rotten, fake, bribe, bad, damaged, likes to accept bribes, misappropriates money/goods belonging to companies or the state, accepts money using his position for personal gain. Corruption also means collecting money for services that should have been provided, or using authority to achieve unauthorized goals. ${ }^{4}$

The international agreement on the definition of corruption is based on the Black Law Dictionary,which is stated that Corruption is done with an intention to give some advantages inconsistence with official duty and the rights of others. The act of an official or fiduciary person who unlawfully and wrongfully uses his station or character to procure some benefits for himself or for another person, contrary to duty and the rights of others. Meanwhile, according to the legal perspective in Indonesia, the definition of corruption is clearly explained in Law No. 31 of 1999 which was amended by Law number 20 of 2001 concerning Eradication of Corruption Crimes. It is explained that corruption is an attempt to enrich oneself or other people or a corporation by way of breaking the law. There are 13 articles in the Act that explain criminal forms of corruption. Based on these articles, there are 30 forms/types of corruption that can be subject to legal sanctions. The thirty forms/types of corruption can basically be grouped as follows:

4 J.C.T Simorangkir, Kamus Hukum (Jakarta:Sinar Grafika, 2006), 89. 
(1) Bribery, (2) Embezzlement in office, (3) Extortion, (4) Fraud, (5) Conflicts of interest in procurement, and (6) Gratuities. In Arabic, one of the terms of corruption is also referred to as rishwah which means bribery. Rishwah is also interpreted as a bribe. Besides being considered a destructive and treasonous act, corruption is also called a fasad and ghulul. From the description above, it can be seen that the meaning and content of the corruption meaning is very broad, depending on the field of perspective carried out.

Corruption has been practiced since the millennium BC by the people of Ancient Greece and Ancient India. In Manu's law for example, it is stated that "corrupt officials who accept bribes from villagers must be driven from their kingdom and their property confiscated." Then in the Roman Empire, corruption is believed to have a greater level of intensity and diversity than corruption in Greece. That was because Rome was a large empire since the 200th century BC which experienced many changes in the economic, political, and cultural fields. Other forms of corruption in Rome, apart from bribery, also included abuse of authority, transaction corruption, extortion, and so on. This famous example of corruption from the Roman emperium occurred on average for judges, at which time judicial power was transferred to the senate in charge of Roman knights, thus judges were vulnerable to accepting bribes to make certain decisions with a tendency. This case was experienced by Governor Gaius Verres (115-34 BC) which he submitted to a large court in the 70th century BC. Reports received that Gaius had successfully bribed many senators who were judges to examine his case or problem, despite the fact that Gaius could not approach the presiding judge, Cicero. In addition, it was found that Gaius Verres blackmailed a parent or relative of a death sentence to determine how the death sentence was 
carried out or so that the death sentence could be buried as humanly as possible. ${ }^{5}$

In the historical frame of the early days of Islam (at the time of the Prophet, Shahabah, and Tabi'in) acts of corruption have been committed by the Arab community at that time. For example in the case of giving gifts to officials, which in the hadith mentioned one of the friends named Ibn al-Lutbiyyah was sent by the Messenger of Allah to withdraw alms in the Bani Sulaim community. As narrated by Bukhari from Abu Hamid asSa'idi said that: "The Prophet assigned a man from the Banu Asad called Ibn al-Lutbiyah to take alms, then after returning he said (to the Prophet):" This is for the Lord and this was given to me ", then the Prophet went up to the pulpit, so did what Sufyan (narrator) said, then the Prophet praised Allah and praised Him and said:" What is this officer, I sent again, saying, "this is for you and this for me? "then try to sit (only) in his parents' house (not to be an officer) and assume he was given a hadish or not? For the sake of the Substance that I am in His hand, then he gets nothing except coming on the Day of Judgment by carrying on his neck, even in the form of camels, cows or goats who all grimace. "Then the Prophet raised his hand until I saw the white of his armpits ( rawi words) and said: "haven't I said?" he repeated three times. (H.R. Bukhari). In the context of the hadith Rasulullah Saw performed an examination of the official after carrying out his duties and stated that the prize received by the officer was a form of corruption (ghulul). ${ }^{6}$

In Indonesia, at the time of the ancient kingdom, corruption practices occurred in the empires of the kingdoms of Singosari, Demak, Majapahit, and other kingdoms, that is, vast lands belonged to the king,

5 Syed Husein Alatas, Sosiologi Korupsi (Jakarta: LP3ES, 1986),12

${ }^{6}$ Syamsul Anwar, Sejarah Korupsi dan Perlawanan Terhadapnya di Zaman Awal Islam; Perspektif Studi Hadis, dalam Hermenia ( Yogyakarta: PPs Sunan Kalijaga Vol.4 No. $12005), 108$. 
and were managed by nobles or princes, whose job was to withdraw tribute, rent or tax on the people, then the people gave the tax to the nobles or prince and kings with a certain percentage. At that time, the form of payment was in the form of money, but it was often they were forced to pay with harsh labor to meet the needs of the kingdom and was sometimes in the form of pressure and torture on the people.7.

\section{CORRUPTION MEANING CATEGORIZATION}

The expansion of the meaning of corruption caused by the development of various cases that occur in the world and specifically Indonesia, encourages the need to examine and re-examine the term corruption more broadly. The following is the categorization of corruption from a judicial review, based on the formulation of articles in Law Number 31 of 1999 concerning Eradication of Corruption. Starting from article 2 to article 13 of the PTPK Law, here are some categories of corruption that can be drawn from the formulation of articles 2 through 13 of the PTPK Law, including:

1. Enrich oneself, enrich others, and enrich the corporation. Enriching means to make richer, which is an act that makes wealth increase. According to Andi Hamzah, making people who are not rich become rich or people who are already rich get richer. ${ }^{8}$

2. Abuse of authority, abuse of opportunity and abuse of facilities. In general, this opportunity is obtained or obtained as a result of the existence of emptiness or weakness of the provisions of the work procedure or deliberate misinterpretation of the provisions. ${ }^{9}$

${ }^{7}$ Husein Alatas, Korupsi, Sifat, Sebab, dan Fungsi (Jakarta: LP3ES, 1987), 8.

8 Andi Hamzah, Korupsi di Indonesia, Masalah dan Pemecahannya (Jakarta: PT Gramedia Pustaka Utama, 1991), 92.

${ }_{9}^{9}$ R. Wiyono, Pembahasan Undang-undang Tindak Pidana Korupsi (Jakarta: Sinar Grafika, 2005), 39. 
3. Bribery. That is the act of giving and promising something to an employee or state administrator so that the employee or state organizer does something or does not do something in his position so that it is contrary to his obligations.

4. Embezzlement. That is mastering by breaking the law of an object that all or part of it belongs to someone else, which is not due to crime. ${ }^{10}$

5. Gratuities. There are gifts to public servants or state administrators. This gift relates to the position of a civil servant or state administrator who receives a gift and is contrary to the obligations or duties of a civil servant or state administrator who receives the gift.11

6. Levies outside the obligation. That is giving work or handing over goods to civil servants or state administrators who ask for or accept work or deliver goods when it is known that the obligation does not actually exist. 12

\section{TEXT AND CONTEXT OF THE VERSE "CORRUPTION" IN THE QUR'AN}

Initially, the Qur'an has mentioned the term corruption through verses related to fraudulent acts of property and abuse of authority. Like, dalw (bribery), ghulul (betrayal), saraqah (theft). However, seeing the increasingly varied definition of corruption, the term has experienced a significant expansion of meaning. The author explains these terms as described below:

\section{Dalw}

Terminology of dalw can be read in al-Qur'an surah al-Baqarah 188:

\footnotetext{
10 Wiyono, 69.

11 Wiyono, 110

12 Wiyono,, 101
} 


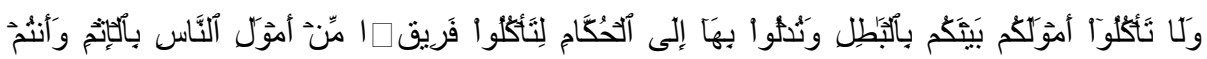

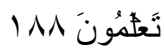

And let not one of you eat the treasure of the other part of you by way of inaccurate and (do not) you bring (the affairs) of that property to the judge, so that you can eat a portion of the property of others by (way of committing) sin, even though you knowing (QS Al-Baqarah-188)

Al-Baqarah is included in the Madaniyyah category, this surah consists of 286 verses. Based on the place where this revelation was revealed, this verse is ranked 87th out of 114 surahs, while in terms of its composition and writing in the Ottoman Manuscripts, this letter is ranked second out of 114 surahs. Based on the asbab an-nuzul, this verse comes down with regard to the case of Umru'ul-Qais ibn 'Abis and' Abdan ibn Ashwa 'Al-Hadrami who are fighting over land. Umru-ul Qais tried to get the land in order to become his property by swearing in front of the judge. While in another source, Ali ibn Abi Talib narrated, from Ibn Abbas, that this verse came down with regard to someone who had dependents on wealth but in this case there were no witnesses to him, then he denied the treasure and disputed it with the authorities. Meanwhile, he himself knew that the treasure was not his right and knew that he was sinful eating illicit goods. ${ }^{13}$

In the book of Tafsir Al-Mishbah, Quraisy Shihab explains His Word: Do not eat your possessions among you in a vanity and lower your scales to the judge, that is, the authority to decide, with the aim that you may eat some of the property of others. by sinning, even though you know the bad thing. The verse can also mean that you should not partly take the property of another person and control it without rights and do

13 Ibn Kathir, Lubab al-Tafsir min Ibn Kathir, terj. M Abdul Ghoffar EM dan Abdurrahim Mu'thi (Bogor: Pustaka Imam Asy-Syafi'i, 2004), Vol.1, 360-361 
not hand over the matter of property to the judge who has the authority to decide the case not for the purpose of obtaining your rights, but to take the rights of others by committing sin, and in a state of knowing that you actually have no right to the treasure. ${ }^{14}$

The word al-bathil is a derivation of the word al-buthlaan which means cheating or harming. According to M. Quraish Shihab the meaning of vanity in this verse is anything that is not right, is not justified by law, and is not in line with divine guidance even though it is done on the basis of willingness to interact. ${ }^{15}$ Whereas the word al-dalw or al-idlaa at first meant reducing the bucket to take water. According to Raghib Asfahani the term dalw is a word loan from التوصّل الى الثيء which means hoping with something as an intermediary. So that the meaning referred to in the above paragraph is bribing a judge, qadhi, and so on who has the authority to release the bribe from the demands or legal snares. ${ }^{16}$

In this verse a bribe is likened to the act of lowering a bucket into a well to obtain water. The lowered bucket is invisible to others, especially to those who are far from the well. The bribe reduces his desire to the authorities to decide something, but clandestinely and with the aim of illegally taking something. One of the efforts to obtain property in a vanity way is to bring property affairs to court, with the aim of seizing the property of others. This can then lead to rishwah, and/or by submitting evidence and arguments to influence the judge's decision. If the above verse is being related to the context of corruption, it contains a very strict meaning forbidding the consuming of other people's property or using property in a vanity manner. Taking property in this way is strictly forbidden in religion. So it can be concluded that when reading

${ }^{14}$ M. Quraish Shihab, Tafsir al-Mishbah, Pesan, Kesan, dan Keserasian al-Qur'an (Jakarta: Lentera Hati, 2011), Vol.1, 497-499.

15 Shihab, Vol.1, 498.

16 Raghib Asfahani, Mufrad fi Gharibil Qur'an (Beirut: Dar al-Ma'rifah), 171. 
this verse from the perspective of the historical setting of the verse, it is clear that the Qur'an strictly forbids financial transactions to "smooth out" cases. ${ }^{17}$

The following table compares the categories of corruption and dalw:

\begin{tabular}{|l|l|}
\hline \multicolumn{1}{|c|}{ Corruption } & \multicolumn{1}{c|}{ Dalw } \\
\hline Enrich Oneself or the others & Enrich Oneself or the others \\
Adverse state finances & Against the law \\
Abuse of authority & Abuse of authority \\
Bribery & Bribery \\
Embezzlement & \\
Gratuity & \\
Levies out of obligation & \\
\hline
\end{tabular}

From the results of the analysis above, it can be concluded that dalw has similarities with four categories of corruption, which is enriching oneself or the others, against the law, abuse of authority, and bribery, because the perpetrators of dalw acts (bribery) both bribe and bribed will abuse their authority to act fairly and become unfair because of the grease money they received

\section{Ghulul}

Ghulul terminology is found in the Qur'an surah Ali 'Imran [3] ayat 161:

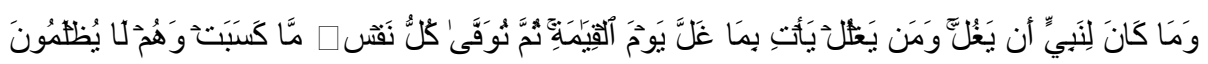
171

It is impossible for a prophet to betray himself in the spoils of war. Whoever betrays the spoils of war, then on the Day of Judgment he will come with what he betrayed, then each person will be given retribution about what he did with (retribution) in kind, while they were not persecuted (QS. Ali Imran 161)

17 M. Quraish Shihab, Tafsir al-Mishbah, Pesan, Kesan, dan Keserasian al-Qur'an, 
Surah Ali 'Imran is included in the madaniyyah category, consisting of 200 verses. Based on the descending order, this surah is 89th out of 114 surahs, while in terms of its composition and writing in the Ottoman Manuscripts, this surah is ranked 3rd of 114 surahs. There are several opinions of 'ulama about asbabun nuzul this verse, broadly speaking, Ibn al-'Arabi in his Ahkamul Qur'an states that there are two things, they are: first, it is reported that the munafiqin actually thought that the Prophet brought some treasures of ghanimah in the form of qotifah (shawl) red from wool are gone, so, this verse was revealed. This is in line with the opinion of Imam Fahruddin Ar-Razi in Mafatihul Ghaib. Second, some of these people take or hide the treasures of Ghanimah, or they think to the Prophet. Then this verse was revealed as a refutation of their refutation. Third, God prevent or forbid saving something from provision. ${ }^{18}$

Fahruddin ar-Razi said the word yaghulla, read fathah in the letter $y a^{\prime}$ and its dhummah ghain and, read Yugholla, then the two qiro'ah bring up some differences because of the decline of the verse, as follows: first read "yaghulla" when the verse prevents or refutes if the Prophet conceals the ghanimah, and cleanses the Prophet of the trait that is incompatible with one of the attributes of the Prophet namely Amanah. Second, it is read "yugholla" when there is an indication that the Prophet has been betrayed by a group of people or sahabah (friends). ${ }^{19}$

According to the history issued by Abu Daud, at-Tirmidhi, Ibn Jarir from Ibn Abbas, that this verse occurred after the battle of Badr and the gathering of booty, then there was a Qatifah lost, it was a red scarf

18 Ibnu Al-'Arabi, Ahkamul Qur'an (Beirut:Dar al-kutub ilmiah), jilid 1, 391. Ibnu Katsir, Tafsir Al-Qur'an Al-'Adzim (Beirut: Dar al-fikr, 1991), juz 1, 15.

19 Fahruddin ar-Razi, Tafsir Kabir au mafatihul ghaib, (Dar al-fad al-arabi, 1992), juz 4, 536. Imam as-Suyuti, ad-Dur al-Mantsur (Beirut: dar al-fikr, 1983), jilid 2, 361. 
(wool) usually used as a head covering in winter. Then, someone said: "maybe the Prophet himself took it for him." This person said not by accusing or making it worse, but thinking, that if he took it, it was his right. However, this history was destroyed by some commentators, because of Ibn Abbas's history of the Uhud War. However, according to the narration corroborated by al-Kalby and Muqatil, indeed, the reason for this verse was revealed was due to the Battle of Uhud. However, the history says that the archers, who were seen as wrong because they left their posts, thought that the spoils would not be distributed to them as they were at the Battle of Badr and when hearing their words, the Prophet Muhammad said: "Do you think we will cheat and will not share with you?" That's why the verse came down. Generally, many scholars always associate this verse with the events of the Battle of Uhud in the 3rd year of Hijriyyah, although there is also another history indicates that this verse was related to a red velvet that was lost during the battle of $\mathrm{Badr}^{20}$

This verse is closely related to the previous verses (Ali 'Imran), where the previous verse talks about God's help, while the above verse talks about treason, while this attribute is one of the main reasons for the absence of God's help. Instead, avoiding betrayal is the main requirement for the presence of His help. The archers left their positions

\footnotetext{
${ }^{20}$ In connection with this issue, Syamsul Anwar, professor in the field of ushul fiqh of the Syari'ah Faculty of UIN Sunan Kalijaga, Yogyakarta, in his writing History of Corruption and Resistance Against it in Early Islam: "Perspective of Hadith Studies," published in Hermenia, Journal of Islamic Studies Interdisciplinary, vol. 4, no. 1, JanuaryJune 2005, p. 112-113, questioning whether the loss of red velvet in the Battle of Badr is true? Al-Tirmidhi states that the hadith that tells this problem as hasan hadith. Syamsul Anwar argued that al-Tirmidzi's research was not final, but could be retested if we look at the sanad from that history. He explained again that the entire version of the narration was reported through Khusaif bin Abdurrahman, and no one else narrated this hadith from the source (teacher) Khusaif so that this Khusaif's history did not have mutaba'ah (not followed by other narratives that support and strengthen). Finally, Syamsul Anwar concluded that the history of the loss of red velvet in the Battle of Badr had no mutaba'ah and should be rejected. If the loss of the red velvet at the Battle of Badr is against the descent of the letter Ali 'Imron (3) verse 161, it does not fit the context of the verse itself in the Qur'an which tells about the battle of Uhud
} 
to take the spoils of war because they were afraid that the spoils would be monopolized by other members of the army who were free to roam the battlefield after seeing signs of defeat of the polytheists at the beginning of the war. In this context, it is reported that the Prophet SAW teased the archers with his saying: "Will we betray and not divide for you ghanimah?" because the archers rushed to leave their positions to take the spoils of war prematurely which led to the decline of the above verse.. ${ }^{21}$

According to Quraysh Shihab in the interpretation of Al-Mishbah: It is not possible at one time or circumstance, a prophet betrayed because one of the absolute qualities of a prophet is a mandate, including being impossible to betray in matters of spoils of war. That is not possible for all prophets, especially Prophet Muhammad, the ruler of the prophets. Whoever betrayed in the spoils of war, or in any case, then on the Day of Judgment he will come with what he betrayed, then each person will be given a perfect retribution in proportion to what he did good or bad while they were not persecuted in the slightest. In fact, those who do good will be given a greater reward. ${ }^{22}$

Etymologically, the word ghulul comes from the verb غلل- يغلل Masdar, invinitive or verbal noun there are several patterns الغل- الغلةشدة العرش everything was interpreted by Ibn al-Manzur with ,وحرارته , which means thirst and extreme heat. ${ }^{23}$ More specifically stated in the dictionary al-Mu'jam al-Wasit that the word ghul of the verb - غلّ خان فى المغنم وغيره it is betrayal in the distribution of Vol.2, 319.

${ }^{21}$ M. Quraish Shihab, Tafsir al-Mishbah, Pesan, Kesan, dan Keserasian al-Qur'an,

22 Shihab, Vol.2, 320.

23 Abu al-Fadhal Jamal al-din Muhammad Ibn Makram Ibn Manzur al-Afriqi alMisri, Lisan al-'Arab (Beirut: Dar Sadir), Vol. 11, 499. 
ghanimah or in other assets. ${ }^{24}$ Meanwhile, al-Maraghi in Tafsir alMaraghi, he explained that the word ghulul in the verse is meaningful which is to take things in hiding. Moreover, this meaning is used in the case of ghanimah theft before being distributed. ${ }^{25}$ Broader than the view of al-Maraghi, M. Quraish Shihab said, the use of the word is a definition of betrayal in general, either betrayal in the context of the mandate submitted for the benefit of the community or certain groups, but in reality used for personal gain. ${ }^{26}$

The terminological definition of ghulul was stated by Rawas Qala'arji and Hamid Sadiq Qunaibi with الأخذ شيء ودسه فى مناعه that is taking something and hiding it in his treasure. ${ }^{27}$ Rasulullah SAW used the term ghulul for two cases:

1. Commission, which is the act of taking an income outside the salary that has been given. Related to this, Rasulullah SAW said:

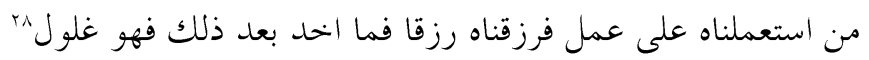

Whoever I raise in one position then I give a salary, then something received outside his salary is Ghulul.

2. Gifts, which is the gifts that a person gets because of the position attached to him. As the Prophet SAW said:

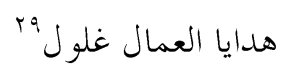

The prize received by the officials is Ghulul

${ }^{24}$ Ibrahim Anis, Abdul Halim Muntasir, dkk. Al-Mu'jam al-Wasit (Mesir: Dar alMa'arif, 1972), 659.

25 Ahmad Mustafa al-Maraghi, Tafsir al-Maraghi (Beirut: Dar al-Kutub al'Ilmiyyah, 2006), 98.

26 M. Quraish Shihab, Tafsir al-Mishbah, Pesan, Kesan, dan Keserasian al-Qur'an, Vol. 2, 320.

27 Muhammad Rawas Qala'arji and Hamid Sadiq Qunaibi, Mu'jam Lughat alFuqaha' (Beirut: Daar al-Nafis, 1985), 334

${ }^{28}$ Abu Dawud Sulaiman, Sunan Abi Dawud (Dar al-Kitab al -'Arabi), Vol. 3, 94.

${ }_{29}$ Ahmad ibn Hanbal, Musnad Imam Ahmad (Riyad: Mu'assasah al-Risalah), Vol. 39, 14. 
From some of the definitions above, etymologically or terminologically, it can be concluded that the term ghulul was initially limited to the level of taking, embezzlement or cheating, and betrayal of the spoils of war. However, the meaning of ghulul has expanded its meaning into fraudulent and treasonous acts against other assets, such as embezzlement of baitul mal, joint property of Muslims, joint property in a business partnership, state property, zakat, commission, gifts (gratuities) and others. Thus, understanding the meaning of ghulul from that point of view, as well as seeing the development of various definitions of corruption and the similarity of their characteristics to corrupt behavior, it is no exaggeration to conclude that ghulul is one of the verses of the Qur'an which is an indicator of the existence of the term corruption in the Qur'an.

This following table is a comparison between the categories of ghulul and corruption:

\begin{tabular}{|l|l|}
\hline \multicolumn{1}{|c|}{ Corruption } & \multicolumn{1}{c|}{ Ghulul } \\
\hline Enrich oneself or the others & Enrich oneself or the others \\
Adverse state finances & Adverse state finances \\
Abuse of authority & Abuse of authority \\
Bribery & Embezzlement \\
Embezzlement & Gratuity \\
Gratuity & \\
Levies out of obligation & \\
\hline
\end{tabular}

From the comparative table analysis above, ghulul which means "to take something and hide it in one's possessions" and "betrayal in the spoils of war" has similar characteristics with the six elements of corruption mentioned above, which is enriching oneself or others, against the law, detrimental to state finances, abuse of authority, embezzlement and gratification, because the meaning of ghulul which 
includes all aspects of betrayal in matters of property, in other words, a person who betray means he misused his authority, whether through embezzlement or receiving gratification. All of them aim to enrich oneself or others, which in turn will adversely affect the country's finances.

3. Saraaqah:

The term saraqah can be found in the Qur'an surah al-Maidah [5] verse of 38th:

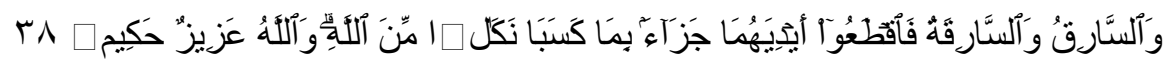

Men who steal and women who steal, cut off both hands (as) retaliation for what they do and as torture from Allah. And Allah is Mighty and Wise (QS Al-Maidah 38)

The verses in this surah are included in the category of surah Madaniyyah, consisting of 120 verses. Related to the descending order of the verse, this surah is 112th out of 114, while in terms of its composition and writing in the Ottoman Manuscripts, this surah is located in the 5th of $114 .{ }^{30}$ In the previous verses Allah mentioned the opposition of the Children of Israel to God's command to fight the arrogant people of the Kan'ans. In the next verse, Allah mentions the story of the two sons of Adam and the disobedience of Qabil to Allah's commands and his killing of a free soul that has been forbidden (his brother). The Jews defied God on earth, they inherited the bad character of the first son of Adam. Both of these stories have similarities in terms of defiance and disobedience. Therefore, Allah calls the punishment of robbers and thieves who damage the security of the State and make damage on earth. ${ }^{31}$

30 M.M. al-A'zami, Sejarah Teks Al-Qur'an (Jakarta: Gema Insani, 2014), 74.

31 Ali al-Sabuni, Safwat al-Tafasir, terj. Yasin (Jakarta: Pustaka al-Kautsar, 2011), Vol. 2, 36-37. 
Ahmad and others narrated from Abdullah bin Amr, he said, "During the time of the Messenger of Allah there was a woman stealing, then her right hand was cut off. Then he asked, "can I still repent 0 Messenger of Allah?" So Allah sent down His commandment to continue this verse: So whoever repents (among the thieves) after committing the crime and correcting himself, then surely Allah accepts his repentance. Truly Allah is Forgiving, Most Merciful (QS. Al-Maidah: 39)

Ali Ash-Shabuni interprets His Word: Male and female thieves, cut off both hands, every thief, both male and female, then cut off his hands, (as) retaliation for what they do, in return for evil deeds. and as a torture from Allah, as a reward from Allah, and Allah is Mighty, Wise in His Shari'a, then He will not order to cut off hands with persecution (without doing wrong). ${ }^{32}$ Etymologically, sariqah is a masdar or verbal noun form of words سرق- يسرق- سرقا which means اخذ ما ليس له اخذه فى خفاء take property that is not his right by stealth. Meanwhile, according to the terminology, saraqah in Islamic Sharia is to take a sum of ten dirhams which is still valid, kept in a safe deposit box or kept and carried out by a mukallaf clandestinely and there is no element of shubhat so if the money is less than ten dirhams that are still valid then it is not categorized as theft. ${ }^{33}$

Saraqah is taking property of another person by stealth from his storage which is used to store the goods or assets. In this case, Abdul Qadir Audah explained in detail about the difference between petty theft and grand theft. In petty theft, the process of taking wealth is not realized by the victim and carried out without his permission, because in petty theft must fulfill both of these elements simultaneously, (ie the

\footnotetext{
32 al-Sabuni, 37.

33 al-Jurjani, Kitab al-Ta'rifat (Jakarta, Dar al-Hikmah), 118.
} 
victim does not know and allow). While grand theft is the taking of property carried out with the aware of the victim, but the victim does not allow it to happen so there is an element of violence. If there is an element of violence inside it is called pickpocketing or mugging. ${ }^{34} \mathrm{M}$. Quraish Shihab distinguishes theft from corruption, robbing, picking pockets and looting. In al-Mishbah's interpretation it is stated that stealing is stealthily taking valuables belonging to others which are kept by their owners in a reasonable place, and thieves are not permitted to enter that place. Therefore, whoever takes something that is not his, but is mandated by him, is not included in the sense of stealing according to this verse. ${ }^{35}$

Certainly what is meant by the opinions above is the understanding of saraqah according to shariah which is consequently threatened with hudud actions in the form of sanction of cutting off hands in Islamic law. However, if it is associated with corruption, the authors argue that the crime of theft can be found in terms of the similarity of elements with acts of corruption. Stealing what is meant here is stealing something that has been entrusted to him which is supposed to be safeguarded by the mandate holder. Basically, in the element of the act of enriching oneself, another person or a corporation that can be detrimental to the country's finances or the country's economy there is a very clear element of the act of stealing. Because in the context of criminal acts of corruption, acts of enriching oneself could not have been possible if it had not been by stealing state treasury money.

The following table compares between saraqah and corruption:

${ }^{34}$ Nurul Irfan, Korupsi dalam Hukum Pidana Islam (Jakarta: Amzah, 2012), 45

35 M. Qurai.sh Shihab, Tafsir al-Mishbah, Pesan, Kesan, dan Keserasian al-Qur'an, Vol.3, 113 . 


\begin{tabular}{|l|l|}
\hline \multicolumn{1}{|c|}{ Corruption } & \multicolumn{1}{c|}{ Saraqah } \\
\hline Enrich oneself or the others & Enrich oneself or the others \\
Adverse state finances & Adverse state finances \\
Abuse of authority & Abuse of authority \\
Bribery & Embezzlement \\
Embezzlement & \\
Gratuity & \\
Levies out of obligation & \\
\hline
\end{tabular}

From the analysis of the table above it can be concluded that saraqah has similarities with four elements of corruption, that is enriching oneself or the others, harming state finances, abuse of authority, and embezzlement, because, saraqah or theft which is embezzled with embezzlement is an act that betrays the trust, it can be said as acts of abuse of authority aimed at enriching temselves or teh others. Saraqah's actions can harm state finances.

\section{Suht}

The terminology of Suht can be found in surah al-Maidah [5] verse of 42nd:

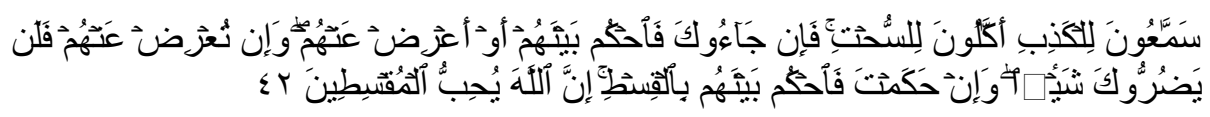

They are people who like to hear false news, eat a lot of unclean food. If they (the Jews) come to you (to ask for a ruling), then decide (the matter) among them, or turn away from them; if you turn away from them they will not give you any harm. And if you decide on their case, then decide (the case) between them fairly, surely Allah likes those who are righteous (QS Al-Maidah 42)

Surah al-Maidah is included in the surah madaniyyah category. This surah consists of 120 verses. Based on the descending order, this surah is ranked 112th out of 114 , while in terms of its composition and writing in the Ottoman Manuscripts, this surah is ranked 5th out of 
114. ${ }^{36}$ This verse is a continuation of the previous verse (al-Ma'idah verse 41), which talks about the characteristics of the Jews. If in the previous verse it was stated that they really like to hear lies and really like to hear the news to be conveyed to others, then in this verse is an explanation of their subsequent habits. ${ }^{37}$

Asbab an-nuzul from this verse begins with a narration about a man from the Fadak who had committed adultery. The Fadak tribal society wrote letters to the Jews in Medina asking them to ask the Prophet Muhammad about the punishment for the adulterer. Then he asked them: "What about the stoning punishment that you get in the book of the Torah?" stoning. "Then they brought the book of the Law and opened it, then one of them put their hands (covered it) in the stoning verse. Then he only reads the verse before and after the stoning verse. So Abdullah bin Salam said to him: "Raise your hand!" So the man raised his hand and it turned out that what was covered was a stoning verse. Then they said: "O Muhammad, you are right, in the Torah there is a stoning verse." Then the Prophet ordered that they be stoned. Then I saw the man of adultery bent to protect her from a stone throw. 38

As Shabuni interpreted: They are people who like to hear false news, these words are repeated to strengthen. Many eat unclean, by bribing judges, usury and others. If they (the Jews) come to you (to ask for a ruling) about the dispute between them, then decide (the matter) between them, or turn away from them. You may act deciding or look away. 39

The term al-suht in the verse is the derivation of the word سحت which has the meaning of obtaining illicit wealth. al-Sha'rawi defines

36 M.M. al-A'zami, Sejarah Teks Al-Qur'an (Jakarta: Gema Insani, 2014), 74. Vol. 3, 125.

37 M. Quraish Shihab, Tafsir al-Mishbah, Pesan, Kesan, dan Keserasian al-Qur'an,

38 Shaleh, Asbabun Nuzul (Bandung: Penerbit Diponegoro, 2011), 196.

${ }^{39}$ Ali al-Sabuni, Safwat al-Tafasir, terj. Yasin, 53. 
that al-suht is any form of effort which is not done in a lawful manner, such as bribery, usury, stealing, snatching, depriving, all types of gambling and betting, all of which are called al-suht. ${ }^{40}$ Al-Raghib alAsfahani named the term al-suht as bribe/rishwah. Al-Zamakhshari in his interpretation of al-Kashshaf said that what is meant by al-suht is illicit property. ${ }^{41}$ al-Tha'labi stated in his interpretation that what is meant by al-suht here is bribery. Furthermore, al-Tabari also wrote in his interpretation that what is meant by al-suht here is bribery/rishwah. ${ }^{42}$ Among the propositions which show that al-suht is rishwah is the interpretation of Hasan al-Basri and Sa'id Ibn Jubair as narrated by Ibn Ruslan. Sentence اكلون للسحت contained in al-Quran surah al-Maidah [5] verse 42 is understood by both with rishwah. Indeed, according to the history of Masruq Ibn Mas'ud when asked about the meaning of al-suht, does it mean rishwah?, he did not say al-suht means rishwah. Then Ibn Mas'ud said, but if there is someone who asks for your help on that person's wrongdoing, then he gives you a gift then don't you accept. 43

With a slightly different editor, al-Qurtubi argues, Ibn Mas'ud's history of the interpretation of the word al-suht, that is, someone who helps pass the needs of his friends, then the person being helped gives a gift and is accepted by the party who has given the gift. In other words, if someone eats because of his power, and he has a position on the side of the ruler, then someone submits a request to him, but he is reluctant

40 M.Mutawalli Sha'rawi, Tafsir Sha'rawi (Kairo: Akhbar al-Yaum), 324

41 Abd al Qasim Mahmud al-Zamakhshari, Tafsir al-Kashshaf (Beirut: Dar al'Ilmiyyah, 1968), Vol. 3, 57.

42 Ibn Jarir al-Tabari, Tafsir al-Tabari (Beirut: Dar al-Kutub al-'Ilmiyyah, 2005),Vol. 4, 580.

43 al-Shawkani, Nail al-Autar (Beirut: Dar al-Fikr),Vol. 9, 172 
to fulfill unless given bribes. Rasulullah SAW condemned bribes and those who were given bribes. ${ }^{44}$

From the analysis of some of the opinions of the mufassirin regarding the meaning of the term al-suht above, it can be concluded that al-suht is part of the term in the Qu'ran that indicates the practice of bribery that is known as one of corruption type behavior models.

The following is a comparison between as-suht and corruption:

\begin{tabular}{|l|l|}
\hline \multicolumn{1}{|c|}{ Corruption } & \multicolumn{1}{|c|}{ Suht } \\
\hline Enrich oneself or the others & Enrich oneself or the others \\
Adverse state finances & Abuse of authority \\
Abuse of authority & Bribery \\
Bribery & \\
Embezzlement & \\
Gratuity & \\
Levies out of obligation & \\
\hline
\end{tabular}

From the comparative analysis between as-suht and corruption in the table above it can be concluded that the suht category has similarities with three categories of corruption, that is enriching oneself or the others, harming state finances, abuse of authority, and bribery, because of acts of suht (as understood), is another word for an act of bribery (rishwah) which means that the action is an act of enriching other people by vanity. In addition, those who are willing to be bribed mean to abuse their authority, which should be proportional to disproportionately.

44 al-Qurtubi, Tafsir al-Qurtubi, terj. Ahmad Khatib (Jakarta: Pustaka Azzam, 2008), Vol.6, 489. 
5. Treacherous

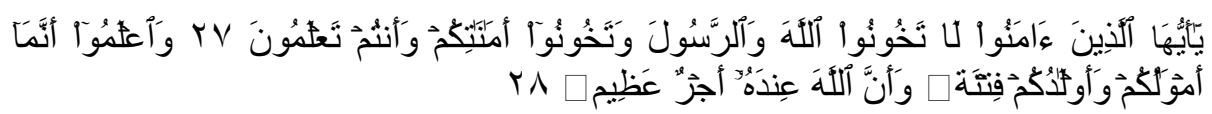

$O$ believers, do not betray Allah and the Prophet (Muhammad) and (also) do not betray the messages entrusted to you, you know. And know that your wealth and your children are only a trial, and indeed in the sight of Allah is a great reward (Al-Anfal: 27-28)

Abdur Razzaq ibn Abu Qatadah and Az-Zuhri said that this verse was revealed with regard to Abu Lubabah ibn Abdul Munzir when the Messenger of Allah. sent him to the Banu Quraizah to deliver his message that they submit to the law of the Prophet. Then the people of the Bani Quraizah asked for advice from Abu Lubabah on this matter, so Abu Lubabah signaled to them with his hands toward his throat, which meant to be slaughtered, which is to die. Then Abu Lubabah realized that his actions meant that he had betrayed Allah and His Messenger. So he vowed that he would not eat to death or that Allah would accept his repentance. Then Abu Lubabah went to the Medina mosque and tied himself to one of the mosque's poles. He stayed in this condition for nine days until he was unconscious due to exhaustion. So Allah revealed the revelation to His Messenger that the repentance of Abu Lubabah was received.

Then people came to him delivering the happy news that God had accepted his repentance. They intended to untie him from the mosque's pillar, but Abu Lubabah swore that no one would release him from the mosque's pillar apart from the Messenger of Allah. with his own two hands. Finally the Messenger of Allah. untied, then said Abu Lubabah, "O Messenger of Allah, verily I have vowed that all my wealth will be spent on alms." Then Rasulullah SAW said, "Suffice it for you by offering it a third of It". 
Ibn Jarir said he had told me Al-Haris. has told us Abdul Aziz, has told us Yunus ibnul Haris At-Taifi, has told us Muhammad ibn Abdullah ibn Aun As-Saqafi, from Al-Mugirah ibn Syu'bah who said that the following verse was revealed regarding the killing of Usman ra, which is His word: 0 you who believe! Do not betray Allah and His Messenger. (Al-Anfal: 27), until the end of the verse. Ibn Jarir also said, had told us Al-Qasim ibn Bisyr ibn Ma'ruf, had told us Syababah ibn Siwar, had told us Muhammad ibnul Muharram who said that he had met with 'Ata ibn Abu Rabah, then' Ata told him that Jabir ibn Abdullah had told him that Abu Sufyan was out of Mecca (traveling). Then Angel Gabriel came to the Prophet. and told him that Abu Sufyan was in such and such a place. Then the Messenger of Allah. said, "Verily, Abu Sufyan is now in such and such a place. Then you go to attack him, but keep your mission a secret." But there was a hypocrite sent a letter to Abu Sufyan, that Muhammad was looking for him, so he was asked to be vigilant. So Allah sent down His words: Do not you betray Allah and His Messenger and (Also) do not betray the mandates entrusted to you ". (Al-Anfal: 27), until the end of the verse.

This hadith is very strange (gharib) while the sanad and the text still need to be considered. In the Sahihain book the story of Hatib ibn Abu Balta'ah is mentioned, that he wrote a letter to the Quraysh to inform them about the plan of the Prophet. against them in the year of victory over the city of Mecca. So Allah showed this to His Messenger. Then Rasulullah Saw sending an army to chase the sender of the letter, until the letter was successfully prevented and returned, then Hatib was confronted with the Messenger of Allah and Hatib admitted his actions. That was when Umar ibnul Khattab rose, then said, "O Messenger of Allah, may I cut off the trunk of his neck, for in fact he has betrayed Allah and His Messenger and the believers?" Rasulullah Saw. Said, "Leave him 
be. because in fact he had participated in the Battle of Badr. You know, hopefully Allah will pay attention to the expert Badar and He says, "Do as you like, verily I have forgiven you."

In our opinion, a valid opinion is that which says that this verse has general meaning, although it is true that this verse was revealed because of a specific background. According to jumhur ulama, what is used is the generality of the meaning it contains, not its specific background. Betrayal is general including all minor sins and major sins which are permanent and not permanent. Ali ibn Abu Talhah has narrated from Ibn Abbas in connection with the meaning of His word: and also do not you betray the mandates entrusted to you. (Al-Anfal: 27) Mandate means something that is entrusted by Allah to His servants, it is things that are fard. It is said he is takhunu meaning you must not damage the message.

According to another narration it says: do not you betray Allah and His Messenger. (Al-Anfal: 27) What is meant by the mandate is to leave His commands and do disobedience. Muhammad ibn Ishaq said, had told me Muhammad ibn Ja'far ibnuz Zubair, from Urwah ibnuz Zubair in connection with the meaning of this verse is 'do not show the truth before him that makes him willing to you, then you oppose it in your heart and tend to other than it; because in fact it destroys your message and is a betrayal of yourself. Saddi said that if they betrayed Allah and His Messenger, they betrayed the messages entrusted to them. He further said that they first heard the conversation of the Prophet, then they leaked it to the polytheists.

In the corruption context, Betrayal includes abusing the trust given from someone or an institution to him. The form of betrayal may not use a managed budget in accordance with its designation, excessive 
mark-up of the project, manipulate financial reporting of the managed project, or even manage a state project by relatives and family so that it easily and freely controls the state budget. Then the following table categorizes betrayal with corruption.

\begin{tabular}{|l|l|}
\hline \multicolumn{1}{|c|}{ Corruption } & \multicolumn{1}{c|}{ Khianat } \\
\hline Enrich oneself or the others & Enrich oneself or the others \\
Adverse state finances & Adverse state finances \\
Abuse of authority & Abuse of authority \\
Bribery & Embezzlement \\
Embezzlement & Levies out of obligation \\
Gratuity & \\
Levies out of obligation & \\
\hline
\end{tabular}

From the table above, it can be seen that the traitors in the text of Al-Anfal 27-28 include the category of enriching oneself, abuse of authority, embezzlement, detriment of state finances, and extortion. In practice, we can be seen in various cases affecting several regional heads in West Java, and price mark-up cases in ministries, departmental agencies under ministries or other state-owned institutions.

\section{CONCLUSION}

Corruption is a massive crime committed by people at various social levels, ranging from state officials to village officials, from politicians to religious figures. Some people argue that corruption is something that is normal to do as a result of such a demanding system, but in the context of Indonesia, corruption is a latent danger that undermines the joints of the country's economic life. The huge loss to the country's finances and economic stability and the rights of the people are taken away by a handful of corruptors. Therefore law enforcement regulated in Law Number 31 of 1999 concerning Eradication of Corruption in Articles 2 through 13, it is necessary to describe the 
categorization of corruption which includes enriching oneself or others, harming state finances, abuse of authority, bribery, embezzlement, gratuity, and levies are outside the obligation.

Likewise in the Islamic perspective, the text of the Qur'an mentions several terms of corruption such as al-dalw (Al-Baqarah: 188), ghulul (Ali Imran: 161), Saraqah (Al-Maidah: 38), and al-suht (Al-Suht Maidah: 42), which in its context experienced an expansion of meaning along with the development of corruption cases that occurred in Indonesia. For example the word al-dalw (Al-Baqarah: 188) implies enriching oneself or others, abuse of authority, and bribery. Ghulul (Ali Imran: 161) implies enriching oneself or others, harming state finances, abuse of authority, embezzlement, gratuity. Then saraqah (Al-Maidah: 38) implies enriching oneself or another person, harming state finances, abuse of authority, embezzlement. And lastly al-suht (Al-Maidah: 42) implies enriching oneself or others, abuse of authority, bribery

\section{REFERENCES}

Al-'Arabi, Ibnu. Ahkamul Qur'an. Beirut:Dar al-kutub ilmiah.

Al-A'zami, M.M. Sejarah Teks Al-Qur'an. Jakarta: Gema Insani Press, 2014. Alatas, Husein. Korupsi, Sifat, Sebab, dan Fungsi. Jakarta: LP3ES, 1987.

Alatas, Syed Husein. Sosiologi Korupsi. Jakarta: LP3ES, 1986.

Al-Jurjani. Kitab al-Ta'rifat,Jakarta. Dar al-Hikmah.

Al-Maraghi, Ahmad Mustafa. Tafsir al-Maraghi. Beirut: Dar al-Kutub al'Ilmiyyah, 2006.

Al-Misri, Abu al-Fadhal Jamal al-din Muhammad Ibn Makram Ibn Manzur al-Afriqi. Lisan al-'Arab, Beirut: Dar Sadir, Vol. 11.

Al-Qurtubi. Tafsir al-Qurtubi, terj. Ahmad Khatib. Jakarta: Pustaka Azzam, Vol.6, 2008. 
Al-Sabuni, Ali. Safwat al-Tafasir, terj. Yasin. Jakarta: Pustaka al-Kautsar, Vol. 2, 2011.

Al-Shawkani. Nail al-Autar. Beirut: Dar al-Fikr,Vol. 9.

Al-Tabari, Ibn Jarir. Tafsir al-Tabari. Beirut: Dar al-Kutub al-'Ilmiyyah, Vol. 4, 2005.

Al-Zamakhshari, Abd al Qasim Mahmud. Tafsir al-Kashshaf. Beirut: Dar al-'Ilmiyyah, Vol. 3, 1968.

Anis, Ibrahim. Abdul Halim Muntasir. Al-Mu'jam al-Wasit. Mesir: Dar alMa'arif, 1972.

Anwar, Syamsul. Sejarah Korupsi dan Perlawanan Terhadapnya di Zaman Awal Islam ; Perspektif Studi Hadis, dalam Hermenia, Yogyakarta: PPs Sunan Kalijaga Vol.4 No. 12005

Ardisasmita, M. Syamsa. Definisi Korupsi Menurut Perspektif Hukum dan Announcement untuk Tata Kelola Pemerintahan yang lebih Terbuka, Transparan dan Akuntabel. Jakarta,: KPK, 2006.

ar-Razi, Fahruddin. Tafsir Kabir au mafatihul ghaib. Dar al-Fad al-Arabi, juz 4, 1992.

Asfahani. Raghib. Mufrad fi Gharibil Qur'an, Beirut: Dar al-Ma'rifah.

as-Suyuti, Imam. ad-Dur al-Mantsur. Beirut: Dar al-Fikr, jilid 2, 1983.

Garner, Bryan A. Black's Law Dictionary. USA: Thomson West, 2004.

Hamka, Tafsir al-Azhar. Pustaka Panjimas, juz III-IV, 2003.

Hamzah, Andi. Kamus Hukum. Jakarta: Ghalia Indonesia, 1986.

. Korupsi di Indonesia, Masalah dan Pemecahannya. Jakarta: PT Gramedia Pustaka Utama, 1991.

- Pemberantasan Korupsi Melalui Hukum Nasional dan Internasional. Jakarta: Raja Grafindo Persada, 2005.

Hanbal, Ahmad ibn. Musnad Imam Ahmad, Riyad: Mu'assasah al-Risalah, Vol. 39.

Irfan, Nurul. Azumardy Azra dalam Korupsi dalam Hukum Pidana Islam. Jakarta: Amzah, 2012.

Irfan, Nurul. Korupsi dalam Hukum Pidana Islam, Jakarta: Amzah, 2012.

Katsir, Ibn. Lubab al-Tafsir min Ibn Kathir, terj. M Abdul Ghoffar EM dan Abdurrahim Mu'thi. Bogor: Pustaka Imam Asy-Syafi'i,Vol. 1, 2004.

Katsir, Ibnu. Tafsir Al-Qur'an Al-'Adzim. Beirut: Dar al-fikr, Juz 1, 1991. 
Klitgaard, Robert. Penuntun Pemberantasan Korupsi dalam Pemerintahan Daerah, terj. Hermoyo. Jakarta: Yayasan Obor Indonesia, 2002.

Munawwir, Ahmad Warson. Kamus Al-Munawwir Arab-Indonesia. Yogyakarta: Ponpes Krapyak al-Munawwir, 1994.

Qala'arji, Muhammad Rawas. dan Qunaibi, Hamid Sadiq. Mu'jam Lughat al-Fuqaha'. Beirut: Daar al-Nafis, 1985.

Sha'rawi, M.Mutawalli. Tafsir Sha'rawi. Kairo: Akhbar al-Yaum

Shaleh. Asbabun Nuzul. Bandung: Penerbit Diponegoro, 2011.

Shihab, M. Quraish. Tafsir al-Mishbah, Pesan, Kesan, dan Keserasian alQur'an. Jakarta: Lentera Hati, Vol.1, 2001.

Simorangkir, J.C.T. Kamus Hukum, Jakarta:Sinar Grafika, 2006.

Sulaiman, Abu Dawud. Sunan Abi Dawud. Dar al-Kitab al -'Arabi, Vol. 3.

Tim Penyusun Laporan Tahunan KPK, Laporan Tahunan 2015 Menolak Surut. Jakarta; Penerbit Komisi Pemberantasan Korupsi, 2016.

Wiyono, R. Pembahasan Undang-Undang Tindak Pidana Korupsi. Jakarta: Sinar Grafika, 2005. 